\title{
PENGENDAIAN MULTIVARIATE DENGAN DIGRAM KONTROL MEWMA ENGGUNAKAN METODE SIX SIGMA (STUDI KASUS PT FUMIRA SEMARANG TAHUN 2019)
}

\author{
Puspita Ayu Utami' ${ }^{1}$, Mustafid ${ }^{2}$, Tatik Widiharih ${ }^{3}$ \\ 1,2,3 Departemen Statistika FSM UNDIP \\ Email: mustafid55@gmail.com
}

\begin{abstract}
As one of the biggest corrugation producing industries, PT Fumira Semarang is always required to fulfill customer needs by continuously improving their quality. Galvanized Steel is the raw material for the production of corrugation at PT Fumira Semarang. There are three important quality characteristics to be controlled in order that the results of galvanized steel production fit the standards to be manufactured as corrugation are waves, rust, and scratches. Six Sigma is a method for controlling quality. Six Sigma has focus on reducing defects, by standard 3,4 defects per one million opportunties. This research aims to identify the galvanized steel production process using Six Sigma method with MEWMA control chart and the capability of the process to fit the standards. Multivariate Exponentially Weighted Moving Average (MEWMA) control chart is a tool used to control multivariate process averages. The result of this research are MEWMA control chart with lambda 0.7 shows that the process is controlled statistically and The Sigma value for waves is 2,33 , for rust 2,05, and for scratches 2,64 . And the research reveals the galvanized steel production process has not fit to the standard because the process capabilty index is 0,2805 .
\end{abstract}

Keywords: Galvanized Steel, Quality Control, Six Sigma, Multivariate Exponentially Weighted Moving Average, Process Capability Analysis

\section{PENDAHULUAN}

Industri baja saat ini merupakan salah satu prioritas yang tengah dikembangkan di Indonesia. Hal ini menjadikan persaingan dalam pasar industri baja semakin ketat dan menuntut para pelaku bisnis untuk menghasilkan segala keunggulan yang mereka miliki agar dapat bersaing. Upaya yang dilakukan dalam menjaga eksistensi usahanya adalah memberikan kepuasan kepada konsumen dengan selalu menjaga kualitas produk.

PT Fumira Semarang adalah perusahaan yang bergerak di bidang pengolahan baja, dimana salah satu produknya adalah galvanized steel. Galvanized steel merupakan bahan baku untuk pembuatan seng gelombang (corrugation). Dalam menuju tujuan perusahaan untuk meminimumkan tingkat kecacatan mendekati zero defect diperlukan pengendalian kualitas. Pada proses pengendalian kualitas sering digunakan metode Six Sigma sebagai terobosan dalam bidang manajemen kualitas dan juga digunakan diagram control sehingga dapat diketahui proses dalam keadaan terkendali atau tidak terkendali.

Dalam penelitian ini terdapat karakteristik kualitas yang diperhatikan dalam produksi galvanized steel yaitu gelombang, karat, dan goresan. Karena terdapat tiga karakteristik kualitas yang diperhatikan dan adanya korelasi antar karakteristik, maka diagram kontrol multivariat tepat digunakan. Menurut Montgomery (2009) 
Multivariate Exponentially Weighted Moving Average (MEWMA) merupakan diagram kontrol multivariat yang digunakan untuk mendeteksi terjadinya perubahan rata-rata proses. Oleh karena itu, dalam penelitian ini dilakukan pengendalian kualitas proses produksi galvanized steel dengan diagram kontrol multivariat Multivariate Exponentially Weighted Moving Average menggunakan metode Six Sigma.

\section{TINJAUAN PUSTAKA}

Galvanized steel adalah produk baja lapis dari gulungan plat putih atau cold rolled stell coil (CRC) yang memiliki lapisan pelindung anti karat (Fumira, 2010). Galvanized steel yang diproduksi PT Fumira Semarang merupakan bahan baku seng gelombang (corrugation). Galvanized steel yang sesuai dengan spesifikasi atau tidak cacat digolongkan kedalam kelas I dan selanjutnya diproses menjadi seng gelombang. Penggolongan tersebut berdasarkan karakteristik kualitas. Karakteristik kualitas galvanized steel adalah sebagai berikut:

a. Gelombang : Plat bergelombang tepi yang cukup besar. Terjadi pada saat penggulungan terlalu kuat dan sisi coil tebal lapisannya.

b. Karat : Terdapat karat hitam maupun karat putih yang terjadi karena pencucian kurang sempurna, pengeringan kurang sesuai atau dari bahan baku yang sudah terdapat karat.

c. Goresan : Satu sisi terjadi lapisan tebal dikarenakan tepi nozzle tersumbat kotoran atau zinc.

Dalam proses produksi terdapat persyaratan atau standar khusus yang perlu diperhatikan untuk menentukan suatu kualitas. Proses produksi yang berlangsung harus mampu beroperasi sesuai dengan tujuan yang sudah ditetapkan oleh perusahaan, sehingga diperlukan adanya pengendalian kualitas. Pengendalian kualitas merupakan usaha untuk mempertahankan mutu atau kualitas dari barang yang dihasilkan, agar sesuai dengan spesifikasi produk yang telah ditetapkan berdasarkan kebijaksanaan pimpinan perusahaan (Assauri, 2010).

\subsection{Six Sigma}

Six Sigma merupakan metode sistematis yang menggunakan pengumpulan data dan analisis statistik untuk menentukan sumber-sumber variasi dan cara-cara untuk menghilangkannya (Harry, 2000). Tujuan dari metode ini adalah memperoleh tingkat kinerja proses produksi dengan 3,4 cacat per satu juta kejadian. Kondisi ini digunakan untuk menjelaskan tingkatan proses menggunakan perhitungan sigma. Menurut Mustafid (2017) dalam pengukuran level sigma, terlebih dahulu dihitung jumlah kegagalan yang menunjukkan banyaknya cacat per-satu juta kesempatan atau yang disebut dengan DPMO (defect per million opportunities). DPMO merupakan ukuran kegagalan dalam proyek Six Sigma yang menunjukkan kerusakan suatu prduk dalam satu juta barang kesempatan. Dalam penelitian ini digunakan konsep Six Sigma DMAIC (Define, Measure, Analyze, Improve, Control).

\subsubsection{Define}

Pada langkah atau fase define adalah awal dari program pengendalian kualitas Six Sigma yang mencakup pemilihan masalah, pemahaman proses-proses produksi, dan pengukuran kepuasan pelanggan mengenai kualitasnya. Aktivitas yang terdapat 
pada langkah ini diantaranya adalah mendefinisikan kriteria pemilihan proyek Six Sigma, membuat peta proses SIPOC (Suppliers, Inputs, Process, Output, Customers) dan menentukan critical to quality (CTQ). Informasi yang terkumpul pada langkah ini didapatkan dengan wawancara langsung dengan bagian quality control dan pengamatan langsung di lapangan.

\subsubsection{Measure}

Langkah kedua pada proses DMAIC adalah pengukuran. Pengukuran berfokus pada pemahaman kinerja proses yang dipilih untu diperbaiki pada saat ini, dan pengumpulan data untuk dianalisis. Terdapat beberapa aktivitas yang dilakukan pada tahap ini, yaitu

a. Uji Korelasi Antar Variabel

Menurut Morrison (1990), uji bartlett merupakan metode pengujian untuk mendeteksi ada atau tidaknya korelasi pada sekelompok data. Pengujian korelasi ini digunakan untuk memenuhi syarat data multivariat, karena antar variabel tersebut saling terkait satu sama lain. Hipotesis yang digunakan dalam Uji Bartlett adalah:

Hipotesis :

$\mathrm{H}_{0}: \mathbf{R}=\mathbf{I}$ (tidak ada korelasi antar variabel)

$\mathrm{H}_{1}: \mathbf{R} \neq \mathbf{I}$ (ada korelasi antar variabel)

Statistik Uji :

dengan

$$
\chi_{\text {hitung }}^{2}=-\left\{n-1-\frac{2 p+5}{6}\right\} \ln |\boldsymbol{R}|
$$

$\mathrm{n}$ : banyaknya observasi

$\mathrm{p}$ : banyaknya karakteristik kualitas

$\mathbf{R}$ : matriks korelasi dari masing-masing variabel

$|\mathbf{R}|$ : determinan matriks korelasi

I : matriks identitas

$\chi_{\left(\alpha, \frac{1}{2} p(p-1)\right)}^{2}$ adalah nilai quantil dari distribusi chi-square dengan tingkat

kepercayaan sebesar $\alpha$ dan derajat bebas sebesar $\frac{1}{2} p(p-1)$.

Daerah kritis : $\mathrm{H}_{0}$ ditolak jika nilai $\chi_{\text {hitung }}^{2} \geq \chi_{\left(\alpha, \frac{1}{2} p(p-1)\right)}^{2}$

b. Uji Distribusi Normal Multivariat

Distribusi normal multivariat merupakan suatu perluasan dari distribusi normal univariat untuk dimensi $\mathrm{p} \geq 2$ dengan variabel-variabel yang dependen (Johnson \& Winchern, 2007). Variabel $\boldsymbol{x}=\left(x_{1}, x_{2}, \ldots, x_{p}\right)$ dikatakan berdistribusi normal multivariat dengan parameter $\boldsymbol{\mu}$ dan $\boldsymbol{\Sigma}$ jika mempunyai fungsi densitas probabilitas:

$$
f(x)=\frac{1}{(2 \pi)^{p / 2}|\Sigma|^{1 / 2}} e^{-\frac{1}{2}(x-\mu)^{\prime} \Sigma^{-1}(x-\mu)}
$$

Langkah-langkah untuk pemeriksaan normalitas dengan membuat $q$ - $q$ plot menurut Johnson dan Wichern (2007) adalah sebagai berikut :

1. Menentukan nilai vektor rata-rata $: \overline{\boldsymbol{x}}$

2. Menentukan nilai matriks variansi-kovariansi : $\mathbf{S}$

3. Menentukan nilai jarak mahalanobis setiap titik pengamatan dengan vektor rataratanya $d_{j}^{2}=\left(\boldsymbol{z}_{\boldsymbol{j}}-\boldsymbol{\mu}\right)^{\prime} \boldsymbol{S}^{-\mathbf{1}}\left(\boldsymbol{z}_{\boldsymbol{j}}-\boldsymbol{\mu}\right), j=1,2, \ldots, \mathrm{n}$ 
4. Mengurutkan nilai $d_{j}^{2}$ dari kecil ke besar : $d_{(1)}^{2} \leq d_{(2)}^{2} \leq \cdots \leq d_{(n)}^{2}$

5. Menentukan nilai $P_{j}=\frac{j-\frac{1}{2}}{n}, j=1,2, \ldots, \mathrm{n}$

6. Menentukan nilai $q_{j, p}\left(P_{j}\right)=\chi_{p}^{2}\left(\frac{j-0.5}{n}\right)$.

7. Membuat scatterplot $d_{j}^{2}$ dengan $q_{j}$

Jika scatterplot cenderung membentuk garis lurus maka dapat dikatakan bahwa data berdistribusi normal multivariat (Haryatmi \& Guritno, 2008). Sedangkan pemeriksaan normal multivariat dengan Kolmogorov-Smirnov menurut sebagai berikut:

Hipotesis

$\mathrm{H}_{0}: F(x)=F_{0}(x)$ (Data pengamatan berdistribusi normal multivariat)

$\mathrm{H}_{1}: F(x) \neq F_{0}(x)$ (Data pengamatan tidak berdistribusi normal multivariat)

Statistik Uji :

Daerah kritis :

$$
D=\operatorname{Sup}\left|S\left(d_{j}^{2}\right)-F_{0}\left(d_{j}^{2}\right)\right|
$$

$\mathrm{H}_{0}$ ditolak jika $D>W_{(1-\alpha)}$ atau nilai $p$-value $<\alpha$ dengan uji dua sisi, dengan $W_{(1-\alpha)}$ adalah nilai dari tabel Kolmogorov-Smirnov dengan kuantil 1- $\alpha$.

c. Diagram Kontrol Multivariate Exponentially Weighted Moving Average (MEWMA)

Menurut Montgomery (2009), diagram kontrol variabel merupakan diagram yang digunakan untuk memonitoring suatu karakteristik kualitas yang dapat diukur dan dinyatakan dalam bilangan. Diagram kontrol multivariat merupakan salah satu teknik utama pada proses pengendalian kualitas statistik yang digunakan untuk mengurangi variasi dalam proses variabel karakteristik kualitas yang diperiksa lebih dari satu variabel atau biasa disebut multivariat.

Sebelum menggunakan diagram kontrol MEWMA, terlebih dahulu melakukan pengontrolan data menggunakan diagram kontrol $T^{2}$ Hotelling. Digram kontrol $T^{2}$ Hotelling merupakan diagram kontrol multivariat yang paling sering digunakan untuk memonitor rata-rata proses produksi dan analog dengan diagram univariat Shewhart $\bar{X}$ (Montgomery, 2009). Perhitungan untuk diagram kontrol $T^{2}$ Hotelling dengan pengamatan individual adalah sebagai berikut:

Nilai vektor rata-rata dari setiap $p$ variat $X_{1 j}, X_{2 j}, \ldots, X_{p j}$

dengan: $\quad n \quad=$ jumlah pengamatan

$$
\bar{X}_{i}=\frac{1}{n} \sum_{j=1}^{n} X_{i j}
$$

$X_{i j} \quad=$ nilai pengamatan variat ke- $i$ pada objek ke-j

$\bar{X}_{i} \quad=$ rata-rata variat ke- $i$

$i \quad=1,2, \ldots, p$ dengan $p$ adalah banyaknya variat

$j \quad=1,2, \ldots, n$ dengan $n$ adalah banyaknya pengamatan

Nilai statistik pada diagram kontrol $T^{2}$ Hotelling untuk masing-masing pengamatan adalah

$$
M_{j}^{2}=\left(X_{i j}-\bar{X}\right)^{\prime} \boldsymbol{S}^{-1}\left(X_{i j}-\bar{X}\right)
$$

$M_{j}^{2}=$ nilai $T^{2}$ Hotelling pengamatan ke- $j$

$\boldsymbol{S}^{\mathbf{1}}=$ invers dari matriks variansi-kovariansi $\boldsymbol{S}$.

Batas kontrol pada diagram $T^{2}$ Hotelling yaitu : 
Batas Kendali Atas $(\mathrm{BKA})=\frac{p(n+1)(n-1)}{n^{2}-n p} F_{\alpha ; p ; n-p}$

Batas Kendali Bawah $(\mathrm{BKB})=0$

dengan :

$F_{\alpha ; p ; n-p}=$ Nilai dari distribusi $F$ dengan taraf signifikansi $\alpha$ dan pembilang $p$, derajat bebas $n-p$.

Proses dikatakan tidak terkendali apabila titik-titik bertingkah secara sistematik atau titik-titik mengalami kenaikan atau penurunan secara beruntun (Montgomery, 2009). Jika pada diagram kontrol $T^{2}$ Hotelling proses tidak stabil, maka memungkinkan data untuk menggunakan diagram kontrol Multivariate Exponentially Weighted Moving Average (MEWMA). Diagram kendali MEWMA adalah salah satu diagram kendali multivariat yang menggunakan data variabel atau kontinu untuk mendeteksi adanya perubahan rata-rata proses pada produksi. Diagram kontrol ini dapat lebih sensitif terhadap pergeseran rata-rata karena memperhatikan data sebelumnya sehingga diagram kontrolnya lebih stabil dan memiliki sifat robust (kekal) terhadap distribusi normal. MEWMA yang didefinisikan sebagai berikut, merupakan generalisasi dari proses untuk data univariat EWMA

$\mathbf{Z}_{0}$ : vektor 0 yang berukuran px 1

$$
Z_{j}=\lambda \boldsymbol{X}_{j}+(1-\lambda) Z_{j-1}
$$

$\boldsymbol{Z}_{\boldsymbol{j}-\mathbf{1}}$ : vektor objek berukuran px1

$\mathbf{X}_{\mathbf{j}}$ : vektor sampel pengamatan objek ke-j dengan $j=1,2, \ldots, n$ dengan ukuran matriks $p \times 1$

$\lambda$ : besarnya pembobot, nilai $0 \leq \lambda \leq 1$

Apabila tidak ada pemilihan pembobot yang berbeda untuk masing-masing karakteristik kualitas maka pembobot $\lambda$ bernilai sama. Untuk menentukan nilai lambda digunakan trial and error sehingga grafik dalam keadaan terkendali. Titik pengamatan yang diplotkan di diagram kendali adalah

$$
T_{j}^{2}=\left(\boldsymbol{Z}_{\boldsymbol{j}}-\overline{\boldsymbol{Z}}\right)^{\prime} \boldsymbol{S}_{\boldsymbol{Z}_{j}}^{-\mathbf{1}}\left(\boldsymbol{Z}_{\boldsymbol{j}}-\boldsymbol{Z}\right)
$$

dengan

$$
\boldsymbol{S}_{Z_{j}}=\frac{\lambda}{2-\lambda}\left[1-(1-\lambda)^{2 j}\right] \boldsymbol{S}
$$

$\boldsymbol{S}_{\boldsymbol{Z}_{\boldsymbol{j}}}$ merupakan matriks varian-kovarian dari $\boldsymbol{Z}_{\boldsymbol{j}}$.

Batas kontrol pada diagram MEWMA yaitu :

$\mathrm{BKA}=\frac{p(n+1)(n-1)}{n^{2}-n p} F_{\alpha ; p ; n-p}$

$\mathrm{BKB}=0$

Pada diagram kontrol MEWMA, proses tidak dikatakan tidak terkendali apabila terdapat nilai $T_{j}^{2}>H$. Sama seperti diagram kontrol $T^{2}$ Hotelling, jika terdapat titik yang mengalami kenaikan atau penurunan secara beuntun maka proses tidak dikatakan terkendali juga.

d. Analisis Kapabilitas Proses

Kapabilitas proses ini merupakan suatu kisaran dimana variasi alami suatu proses terjadi akibat penyebab umum suatu system, atau dengan kata lain pencapaian suatu proses dalam kondisi stabil (Evans \& Lindsay, 2007). Untuk mengukur suatu kapabilitas suatu proses digunakan indeks kapabilitas proses. Dalam peneilitian ini hanya terdapat batas spesifikasi atas (USL) dan nilai target (T) tidak ditentukan oleh perusahaan. Menurut Gaspersz (2002) jika nilai target 
tidak (T) tidak ditetapkan, maka nilai $\mathrm{T}$ dapat diganti dengan rata-rata. Suatu proses produksi berjalan secara capable apabila nilai $\mathrm{C}_{\mathrm{pm}} \geq 1$. Perhitungan indeks $\mathrm{C}_{\mathrm{pm}}$ untuk data univariat adalah

Keterangan:

$$
C_{p m}\left(Z_{i}\right)=\frac{\left|U S L-\bar{Z}_{i}\right|}{\sqrt[3]{{S_{Z_{i}}}^{2}}}
$$

USL: Batas spesifikasi atas

$\bar{Z}_{l}$ : Rata-rata tiap variabel setelah transformasi

$S_{z_{i}}:$ Standar deviasi dari $Z_{i}$ untuk $i=1,2, \ldots, p$

Dalam penelitian ini terdapat tiga karakteristik kualitas sehingga indeks kapabilitas multivariat cocok digunakan. Dalam menghitung nilai indeks kapabilitas multivariat digunakan pembobot dari masing-masing kapabilitas karakteristik kualitas yang ditetapkan oleh perusahaan. Jika tidak ada pembobotan untuk masing-masing kapabilitas karakteristik kualitas, maka nilai pembobot dianggap sama. Perhitungannya adalah sebagai berikut (Raissi, 2009):

$$
M C_{p m}=\sum_{i=1}^{p} W_{i} C_{p m}\left(Z_{i}\right)
$$

dimana $M C_{p m}$ merupakan $C_{p m}$ multivariat dengan pembobot $\mathrm{W}_{\mathrm{i}} \cdot \mathrm{W}_{\mathrm{i}}$ merupakan pembobot berdasarkan kepentingan dengan $\sum_{i=1}^{p} W_{i}=1$.

e. DPMO dan Level Sigma

Perhitungan nilai Defect per Million Oppurtunities (DPMO) untuk mengetahui sudah sampai sigma berapakah proses produksi perusahaan tersebut. Penerapan DPMO memungkinkan untuk mendefinisikan kualitas secara lebih luas. Perhitungan DPMO pada data variabel adalah

Cacat yang berada diatas nilai USL (upper specification limit) dengan rumus :

$$
P\left[Z \geq \frac{\left(U S L-\bar{z}_{i}\right)}{S_{z_{i}}}\right] \times 1000000
$$

Cacat yang berada dibawah nilai LSL (lower specification limit) dengan rumus:

$$
P\left[Z \leq \frac{\left(L S L-\bar{z}_{i}\right)}{S_{z_{i}}}\right] \times 1000000
$$

$i=1,2, \ldots, p$ dengan $p$ merupakan banyaknya variabel.

Nilai sigma dengan dua cara yaitu mengkonversikan DPMO kedalam nilai sigma dengan bantuan tabel konversi DPMO ke nilai sigma atau dengan menggunakan Microsoft Excel

$$
\text { Nilai Sigma }=\text { normsinv }\left(1-\frac{D P M O}{1000000}\right)+1,5
$$

dalam penuliasan tugas akhir ini digunakan perhitungan cacat yang berada diatas nilai USL karena hanya terdapat batas spesifikasi atas saja.

\subsubsection{Analyze}

Langkah ketiga adalah menganalisis dengan pemeriksaan terhadap proses, dan data untuk mendapatkan pemahaman mengenai mengapa suatu permasalahan terjadi dan di mana terdapat kesempatan untuk melakukan perbaikan. Terdapat beberapa aktivitas dalam tahap ini yaitu:

a. Diagram Sebab Akibat

Diagram sebab akibat atau biasa disebut diagram fishbone adalah metode grafis sederhana untuk membuat hipotesis mengenai rantai penyebab dan akibat serta untuk menyaring potensi penyebab dan mengorganisasikan hubungan antar variabel (Evans \& Lindsay, 2007). Terdapat lima faktor penyebab utama yang perlu 
diperhatikan, yaitu manusia, mesin, lingkungan, metode kerja, dan bahan baku. Dalam pembuatan fishbone, sumbang saran dari pihak perusahaan sangat efektif untuk menemukan penyebab permasalahan.

\section{b. Failure Mode and Effect Analysis (FMEA)}

FMEA digunakan untuk mengidentifikasi dan menganalisa suatu kegagalan dan akibatnya untuk menghindari dari suatu proses produksi. Failure Mode and Effect Analysis (FMEA) memberikan prioritas perbaikan pada penyebab cacat (Evans \& Lindsay, 2007). Dalam pembuatan FMEA terdapat penetapan tiga aspek Severity, Occurance, dan Detection. Pemberian nilai atau skor untuk ketiga aspek tersebut diberikan oleh pihak perusahaan. Selanjutnya menentukan nilai Risk Priority Number (RPN) dengan rumus

$$
R P N=\text { severity rating } \times \text { occurance rating } \times \text { detection rating }
$$

\subsubsection{Improve dan Control}

Langkah improve diterapkan rencana tindakan untuk melakukan pengendalian kualitas berupa rancangan perbaikan kualitas yang diharapkan dapat mengoptimalkan performa perusahaan. Langkah control merupakan cara untuk mempertahankan perubahan yang dibuat dalam fase improve. Pada penelitian ini tahap improve dan control tidak dilakukan. Penelitian hanya berfokus pada menganalisis bagaimana proses produksi yang ada di PT Fumira Semarang.

\section{METODOLOGI PENELITIAN}

\subsection{Objek Penelitian}

Penelitian ini dilakukan pada proses produksi galvanized steel di PT Fumira Semarang pada tahun 2019. Data yang digunakan pada penelitian ini adalah data karakteristik kualitas galvanized steel di PT Fumira Semarang tanggal 1 April 2019 sampai dengan 27 Juni 2019. Produksi galvanized steel dipilih karena merupakan bahan untuk membuat seng gelombang (corrugation). Hanya galvanized steel dengan kualitas baik atau kelas I saja yang akan dapat dijadikan seng gelombang (corrugation). Penentuan kualitas baik atau tidak suatu galvanized steel berdasarkan karakteristik kualitas yaitu gelombang, karat, dan goresan.

\subsection{Variabel Penelitian}

Data yang digunakan dalam penulisan tugas akhir ini adalah data karakteristik kualitas galvanized steel di PT Fumira Semarang yang berupa data pengukuran atau kontinu dengan variabel penelitian sebagai berikut:

$\mathrm{X}_{1}=$ Gelombang

$\mathrm{X}_{2}=$ Karat

$\mathrm{X}_{3}=$ Goresan

\subsection{Metode Penelitian}

Metode yang digunakan pada penelitian tugas akhir ini adalah Six Sigma menggunakan DMAIC. Penerapan Six Sigma DMAIC merupakan terobosan dalam manajemen mutu sutu proyek. Penelitian ini mengacu kepada berbagai kondisi dimana baik atau buruknya kualitas dari sebuah proyek produksi. Penerapan Six 
Sigma dalam penelitian ini diharapkan dapat meningkatkan atau mengendalikan kualitas produksi menjadi lebih baik.

\subsection{Tahapan Penelitian}

Tahapan analisis data yang dilakukan dalam penelitian ini adalah sebagai berikut:

1. Mewawancarai bagian quality untuk mengtahui proses yang dapat dijadikan sebagai proyek Six Sigma.

2. Mendefinisikan proses yang menjadi proyek six sigma, membuat peta proses SIPOC.

3. Menentukan karakteristik kualitas (Critical to Quality).

4. Mengumpulkan data karakteristik kualitas galvanized stell pada bulan April, Mei, dan Juni 2019 di PT Fumira Semarang.

5. Melakukan pengujian korelasi terhadap variabel cacat produksi

6. Melakukan analisis data pengontrolan cacat produksi dengan menggunakan Diagram Kontrol Multivariate Exponentially Weighted Moving Average (MEWMA) dengan sebelumnya melakukan pengontrolan data menggunakan $T^{2}$ Hotelling. Langkah dalam melakulan pengontrolan menngunakan MEWMA sebagai berikut :

- Menentukan nilai pembobot dengan trial and error

- Menghitung vektor MEWMA, $\mathrm{Z}_{\mathrm{j}}$

- Menghitung matriks varians-kovarians berdasarkan $Z_{j}$

- Menghitung nilai statistik $T_{j}^{2}$ pada setiap pengamatan

- Menghitung BKA dan BKB

- Membuat plot $T_{j}^{2}$ dengan batas kendali dari nilai pembobot yang telah ditentukan

7. Melakukan pengujian distribusi normal multivariat terhadap variabel cacat produksi.

8. Mengukur baseline kinerja di PT Fumira Semarang.

9. Menghitung kapabilitas proses.

10. Menganalisis penyebab permasalahan dari hasil pengamatan langsung dan wawancara dengan bagian quality control.

11. Memberikan usulan tindakan perbaikan.

12. Membuat kesimpulan.

13.

\section{HASIL DAN PEMBAHASAN}

\subsection{Define}

Proyek Six Sigma yang dipilih adalah proses produksi galvanized steel untuk bahan baku pembuatan seng gelombang (corrugation) tipe C. Proyek ini dipilih karena PT Fumira Semarang hanya memproduksi galvanized steel untuk tipe C. Pada produksi galvanized steel, kelas II banyak ditemukan. Penjualan galvanized steel kelas II mengakibatkan keuntungan tidak dapat maksimal. Penggolongan kelas ini berdasarkan karakteristik kualitas, yaitu gelombang, karat, dan goresan.

Selanjutnya pada langkah define, dilakukan pembuatan peta proses SIPOC yang memberikan gambaran bagaimana langkah-langkah proses bekerja. Peta proses yang ditunjukkan Gambar 1. 


\begin{tabular}{|c|c|c|c|c|}
\hline SUPPLIER & INPUT & PROCESS & OUTPUT & CUSTOMER \\
\hline $\begin{array}{c}\text { PT Krakatau } \\
\text { Steel }\end{array}$ & $\begin{array}{l}\text { Cold Rolled } \\
\text { Steel Coil }\end{array}$ & Annealing & $\begin{array}{l}\text { Galvanized } \\
\text { Steel }\end{array}$ & $\begin{array}{l}\text { Shearing } \\
\text { Line }\end{array}$ \\
\hline & & $\begin{array}{c}\text { Hot Dip } \\
\text { Galvanizing } \\
\downarrow \\
\text { Skin Pass }\end{array}$ & & \\
\hline
\end{tabular}

Gambar 1. Diagram SIPOC

Berdasarkan Gambar 1 proses yang menjadi fokus dari project. Terdapat elemen supplier raw material yang digunakan adalah dari PT Krakatau Steel. Cold Rolled Steel Coil (CRC) merupakan input dari proses pembuatan galvanized steel. Pada proses pembuatan galvanized steel dimulai dari annealing, hot dip galvanizing lalu skin pass. Output dari proses produksi ini galvanized steel. Lalu customer dari proses ini adalah proses shearing line. Untuk menentukan cacat, langkah yang harus ditentukan adalah Critical to Quality (CTQ), yaitu mengelompokkan karakteristik jenis cacat produk, yaitu gelombang, karat, dan goresan.

\subsection{Measure}

\subsubsection{Uji Korelasi Antar Variabel}

Penghitungan uji korelasi Bartlett dengan menggunakan hipotesis berikut:

$\mathrm{H}_{0}: \mathbf{R}=\mathbf{I}$ (tidak ada korelasi antar variabel)

$\mathrm{H}_{1}: \mathbf{R} \neq \mathbf{I}$ (ada korelasi antar variabel)

Taraf Signifikansi $\alpha=5 \%$

Statistik Uji :

$\chi_{\text {hitung }}^{2}=13,193609296$

p-value $=0,004236083$

$\mathrm{H}_{0}$ ditolak, karena nilai $\chi_{\text {hitung }}^{2}$ sebesar $13,193609296>\chi_{(0.05,3)}^{2}$ sebesar 7,81473 dan $p$-value bernilai $0,004236083<\alpha$ sebesar 0,05 sehingga dapat disimpulkan bahwa ketiga variabel pada karakteristik kualitas galvanized steel terdapat korelasi.

\subsubsection{Uji Normalitas Multivariat}

a. Uji Secara Visual

Uji normalitas multivariate secara visual diperlihatkan pada Gambar 2. Berdasarkan Gambar 2, dapat disimpulkan bahwa plot normal multivariat $\left(d_{j}^{2}, q_{j}\right)$ cenderung membentuk garis lurus. Sehingga secara visual, data berdistribusi normal multivariat.

b. Uji Formal

Uji secara formal menggunakan Kolmogorov-Smirnov untuk keseluruhan variat dengan hipotesis berikut:

$\mathrm{H}_{0}$ : Data pengamatan berdistribusi normal multivariat

$\mathrm{H}_{1}$ : Data pengamatan tidak berdistribusi normal multivariat

Taraf signifikansi $\alpha=5 \%$

Statistik Uji :

$D=0,072429$ 
$p$-value $=0,9341$

$\mathrm{H}_{0}$ diterima, karena nilai $\mathrm{D}=0,072429<$ nilai pada table Kolmogorov-Smirnov sebesar 0,18904 dan $p$-value bernilai 0,9341 > $\alpha$ sebesar 0,05. Dapat disimpulkan bahwa data karakteristik kualitas produksi galvanized steel berdistribusi normal multivariat.

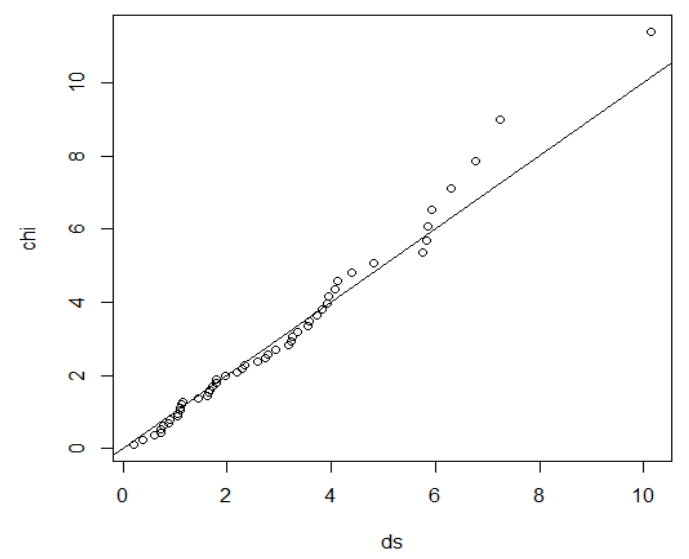

Gambar 2. Plot Normal Multivariat dengan Software R

\subsubsection{Diagram Kontrol Multivariate Exponentially Weighted Moving Average (MEWMA)}

Proses harus terkendali sebelum menghitung kemampuan proses multivariat. Pengendali rata-rata proses dilakukan dengan menggunakan diagram kontrol Multivariate Exponentially Weighted Moving Average (MEWMA). Sebelum menggunakan diagram kontrol MEWMA dilakukan pengendalian menggunkaan diagram kontrol $\mathrm{T}^{2}$ Hotelling untuk memperkuat penggunaan diagram kontrol MEWMA.

Berikut ini merupakan hasil pengendalian rata-rata proses produksi galvanized steel dengan menggunakan diagram kontrol $\mathrm{T}^{2}$ Hotelling yang terdapat pada Gambar 3 .

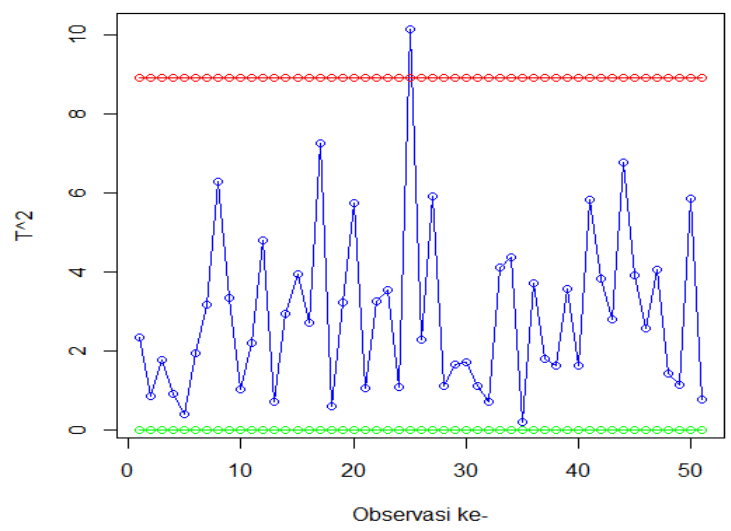

Gambar 3. Diagram Kontrol $\mathrm{T}^{2}$ Hotelling

Berdasarkan Gambar 3 terlihat bahwa proses produksi galvanized steel belum terkendali secara statistika. Hal tersebut dilihat dari terdapat satu titik berada diluar antara Batas Kendali Atas (BKA) sebesar 8,9154 dan Batas Kendali Bawah (BKB) sebesar 0. Karena menggunakan diagram $T^{2}$ Hotelling tidak terkendali, 
memungkinkan dibuat pendekatan Multivariate Exponentially Weighted Moving Average (MEWMA). Hasil pengendalian rata-rata proses produksi galvanized steel menggunakan diagram control Multivariate Exponentially Weighted Moving Average (MEWMA) dengan $\lambda=0,7$ terdapat pada Gambar 4 .

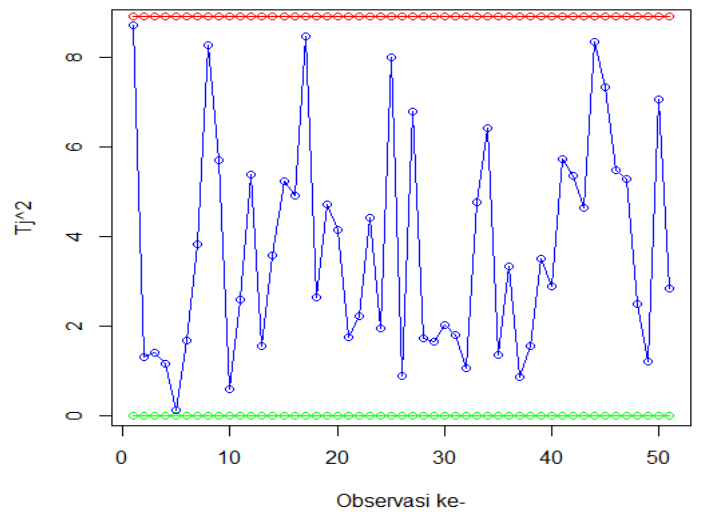

Gambar 4. Diagram Kontrol MEWMA

Berdasarkan Gambar 4 terlihat bahwa proses produksi galvanized steel telah terkendali secara statistika. Hal tersebut terlihat dari plot-plotnya yang berada diantara Batas Kendali Atas (BKA) sebesar 8,9154 dan Batas Kendali Bawah (BKB) sebesar 0 .

\subsubsection{Analisis Kapabiitas Proses}

Analisis kapabilitas proses pada penelitian ini berguna untuk mengetahui keseluruhan kinerja dari proses produksi galvanized steel di PT Fumira Semarang. Indeks yang digunakan untuk mengukur kapabilitas proses dalam penelitian adalah $\mathrm{C}_{\mathrm{pm}}$ ketika data pengamatan telah terkendali secara statistik. Suatu proses dikatakan sesuai standar apabila nilai indeks yang dihasilkan lebih dari 1. Batas spesifikasi atas yang sudah ditentukan perusahaan dan target untuk tiap karakteristik kualitas gelombang, karat, dan goresan galvanized steel dapat dilihat pda Tabel 1.

Tabel 1. Batas Spesifikasi Karakteristik Kualitas

\begin{tabular}{ccc}
\hline Variabel & Batas Spesifikasi Atas & Target \\
\hline Gelombang & $250 \mathrm{~kg}$ & 152,7059 \\
\hline Karat & $250 \mathrm{~kg}$ & 159,902 \\
\hline Goresan & $250 \mathrm{~kg}$ & 142,8039 \\
\hline
\end{tabular}

Nilai tersebut terlebih dahulu diubah ke dalam bentuk setelah transformasi (z). Adapun hasil transformasi untuk nilai batas spesifikasi atas dan target untuk masing-masing karakteristik kualitas dapat dilihat pada Tabel 2.

Tabel 2. Nilai Transformasi Batas Spesifikasi Atas dan Target

\begin{tabular}{ccc}
\hline Variabel & Batas Spesifikasi Atas & Target \\
\hline Gelombang & 175 & 151,5944 \\
\hline Karat & 175 & 158,2344 \\
\hline Goresan & 175 & 141,4506
\end{tabular}

Perhitungan indeks kapabilitas proses secara univariat untuk karakteristik kualitas gelombang diperoleh nilai $\mathrm{C}_{\mathrm{pm}}$ sebesar 0,2766. Sedangkan indeks kapabilitas proses secara univariat untuk karakteristik kualitas karat dan goresan 
berturut-turut adalah sebesar 0,1844 dan 0,3806. Setelah dilakukan analisis kapabilitas secara univariat, dilakukan perhitungan nilai $\mathrm{MC}_{\mathrm{pm}}$, diperoleh sebesar 0,2805. Nilai $\mathrm{MC}_{\mathrm{pm}}$ kurang dari 1 menandakan bahwa secara multivariat kinerja proses belum berjalan sesuai standar. Ketika proses belum berjalan sesuai standar maka disarankan untuk mengendalikan proses produksi agar sesuai standar dan mencapai 3,4 cacat per satu juta kesempatan dengan mencari tahu penyebab terjadinya cacat.

\subsubsection{Menghitung Level Sigma}

Selanjutnya adalah mengukur kinerja baseline atau level sigma proses produksi. Batas spesifikasi yang terdapat pada proses produksi galvanized steel hanya USL (Upper Specification Limit). Hasil DPMO dan level sigma dapat dilihat pada Tabel 3.

Tabel 3. Nilai DPMO dan Sigma

\begin{tabular}{ccc}
\hline Variabel & DPMO & Sigma \\
\hline Gelombang & 203.363 & 2,33 \\
\hline Karat & 290.037 & 2,05 \\
\hline Goresan & 126.739 & 2,64 \\
\hline
\end{tabular}

Berdasarkan Tabel 3 didapatkan variabel karat memiliki DPMO tertinggi yaitu sebesar 290.037 dan goresan dengan DPMO terendah sebesar 126.739. Untuk variabel karat menandakan dari satu juta kesempatan terdapat 290.037 dengan kemungkinan proses produksi galvanized steel belum dapat memenuhi batas spesifikasi karat yang telah ditentukan. Level sigma terendah terdapat pada karat sebesar 2,05 dan level sigma tertinggi pada variabel goresan sebesar 2,64. Pada ketiga karakteristik kualitas menghasilkan level sigma dibawah $3 \sigma$, ini menandakan bahwa proses produksi galvanized steel di PT Fumira Semarang masih kurang kompetitif (George, 2002).

\subsection{Analyze}

Pada tahap selanjutnya adalah menganalisis permasalahan dari proses produksi. Tahap analyze dilakukan dengan mancari penyebab dan akar masalah terjadinya cacat pada proses produksi galvanized steel. Terdapat beberapa langkah yang dilakukan dalam mencari penyebab akar masalah tersebut, yaitu membuat diagram sebab akibat (fishbone diagram), FMEA, dan rekomendasi tindakan perbaikan.

\subsubsection{Diagram Sebab Akibat}

Penyebab-penyebab kecacatan diperoleh dengan pengamatan langsung di lapangan dan wawancara dengan bagian quality control. Diagram sebab akibat pada cacat kelas 2 dapat ditunjukkan pada Gambar 5.

\subsubsection{Failure Mode and Effect Analysis (FMEA)}

FMEA digunakan untuk menentukan prioritas perbaikan penyebab cacat pada galvanized steel dengan menghitung Risk Priority Number (RPN) berdasarkan penilaian tiga aspek yaitu severity, occurence, dan detection. Penilaian tiga aspek ini dilakukan oleh bagian quality control. Tabel FMEA ditunjukkan pada Tabel 4.

\section{Mesin}




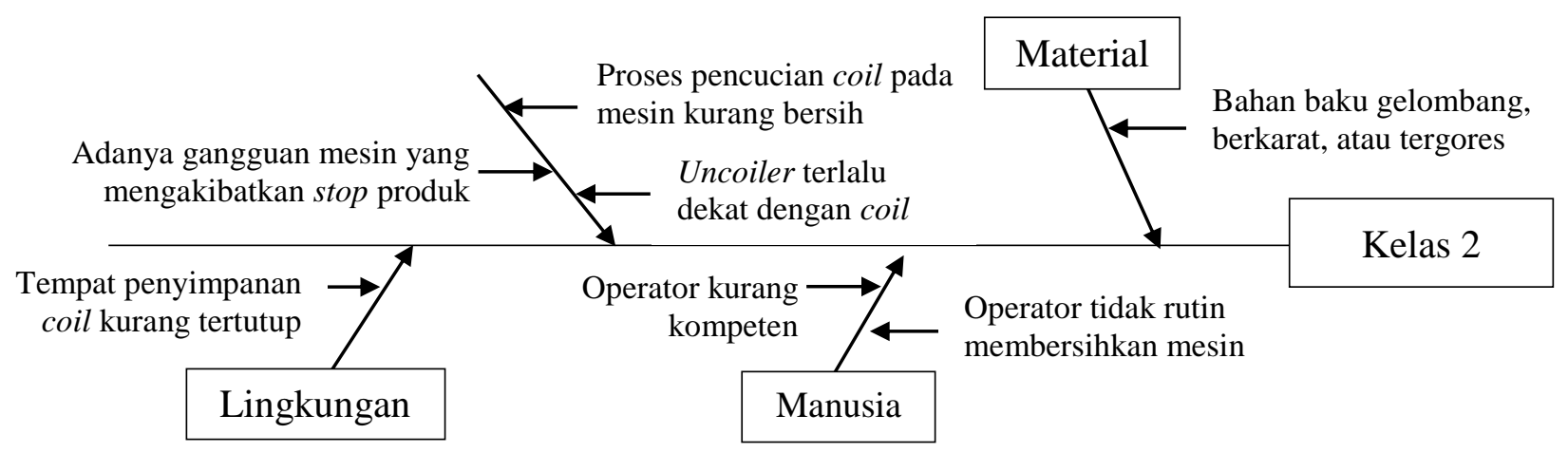

Gambar 5. Diagram Sebab Akibat Kelas 2

Tabel 4. Failure Mode and Effect AnalysiS (FMEA)

\begin{tabular}{|l|l|l|l|l|l|c|c|}
\hline Failure Mode & Cause of Failure & Effect of Failure & S & O & D & RPN & Rank \\
\hline $\begin{array}{l}\text { Kualitas coil } \\
\text { jelek }\end{array}$ & $\begin{array}{l}\text { Bahan baku sudah } \\
\text { bergelombang, } \\
\text { karat, atau gores }\end{array}$ & $\begin{array}{l}\text { Kualitas } \\
\text { galvanized steel } \\
\text { tidak baik }\end{array}$ & 7 & 4 & 3 & 84 & 3 \\
\hline $\begin{array}{l}\text { Coil terkena } \\
\text { hujan }\end{array}$ & $\begin{array}{l}\text { Tempat } \\
\text { penyimpanan coil } \\
\text { kurang tertutup }\end{array}$ & Coil berkarat & 6 & 2 & 2 & 24 & 6 \\
\hline $\begin{array}{l}\text { Galvanisasi } \\
\text { kurang baik }\end{array}$ & $\begin{array}{l}\text { Pencucian coil } \\
\text { kurang bersih }\end{array}$ & $\begin{array}{l}\text { Coil tidak } \\
\text { tergalvanis } \\
\text { sempurna }\end{array}$ & 7 & 4 & 6 & 168 & 1 \\
\hline $\begin{array}{l}\text { Terjadi } \\
\text { stopping line }\end{array}$ & $\begin{array}{l}\text { Adanya gangguan } \\
\text { mesin }\end{array}$ & $\begin{array}{l}\text { Setting mesin } \\
\text { berubah }\end{array}$ & 4 & 3 & 3 & 36 & 5 \\
\hline $\begin{array}{l}\text { Setting } \\
\text { uncoiler } \\
\text { berubah }\end{array}$ & $\begin{array}{l}\text { Uncoiler terlalu } \\
\text { dekat dengan coil }\end{array}$ & $\begin{array}{l}\text { Terjadi gesekan } \\
\text { dan timbul } \\
\text { gelombang }\end{array}$ & 5 & 4 & 2 & 40 & 4 \\
\hline $\begin{array}{l}\text { Operator } \\
\text { kurang } \\
\text { paham } \\
\text { prosedur }\end{array}$ & $\begin{array}{l}\text { Operator kurang } \\
\text { kompeten }\end{array}$ & $\begin{array}{l}\text { Pemeliharaan } \\
\text { mesin kurang } \\
\text { terjaga }\end{array}$ & 2 & 2 & 1 & 4 & 7 \\
\hline Mesin kotor & $\begin{array}{l}\text { Operator tidak } \\
\text { rutin } \\
\text { membersihkan } \\
\text { mesin }\end{array}$ & $\begin{array}{l}\text { Menimbulkan } \\
\text { goresan }\end{array}$ & 7 & 4 & 4 & 112 & 2 \\
\hline
\end{tabular}

Berdasarkan Tabel 4 nilai RPN tertinggi adalah 168 untuk proses galvanisasi yang disebabkan proses pencucian coil pada mesin kurang bersih. Dengan nilai severity sebesar 7 yang menandakan pengaruh buruk yang tinggi, nilai occurrance sebesar 4 yang menandakan kesalahan kadang terjadi dan nilai detection sebesar 6 yang menandakan tingkat deteksi agak sulit.

\section{KESIMPULAN}

Berdasarkan analisis dan pembahasan yang diperoleh pada bab sebelumnya, dapat disimpulkan bahwa diagram kontrol Multivariate Exponentially Weighted 
Moving Average merupakan salah satu alat untuk mengontrol rata-rata proses produksi. Penerapan diagram kontrol Multivariate Exponentially Weighted Moving Average (MEWMA) pada data karakteristik kualitas proses produksi galvanized steel di PT Fumira Semarang menunjukkan bahwa plot-plot berada diantara Batas Kendali Atas (BKA) dan Batas Kendali Bawah (BKB) dengan $\lambda=0.7$ yaitu sebesar 8,9153 dan 0. Nilai kapabilitas proses multivariat yang dihasilkan yaitu 0,2805 yang berarti bahwa kapabilitas proses multivariat pada proses produksi galvanized steel belum berjalan sesuai dengan standar. Dan level sigma yang dihasilkan untuk gelombang sebesar 2,33, untuk karat sebesar 2,05 dan untuk goresan sebesar 2,64.

\section{DAFTAR PUSTAKA}

Assauri, S. 2010. Manajemen Pemasaran. Jakarta: Raja Grafindo Persada.

Evans, J. R., \& Lindsay, W. M. 2007. Pengantar Six Sigma: An Intoduction to Six Sigma \& Process Improvement. Diterjemahkan oleh: Afia R. Fitriati. Jakarta: Salemba Empat.

Fumira. 2010. Material and Process. http://www.fumira.co.id/fumira/index. php?option=com_content\&view=article\&id=104\&Itemid=97. Diakses : 7 Juni 2019

Gaspersz, V. 2002. Pedman Implementasi Program Six Sigma Terintegrasi Degan ISO 9001:2000, MBNQA, dan HACCP. Jakarta: PT Gramedia Pustaka Utama.

George, M. L. 2002. Lean Six Sigma: Combining Six Sigma Quality with Lean Production Speed. New York: McGraw-Hill.

Haryatmi, S., \& Guritno, S. 2008. Metode Statistika Multivariat. Jakarta: Universitas Terbuka.

Johnson, R., \& Wichern, D. 2007. Applied Multivariate Statistical Analysis 6th Edition . United States of America: Pearson Education.

Diterjemahkan oleh: Bob Sabran. Jakarta: Erlangga.

Montgomery, D. C. 2009. Introduction to Statistical Quality Control 6th Edition. United States of America: John \& Wiley Sons, Inc.

Morrison, D. 1990. Multivariate Statistical Methods 3th Edition. New York: Mc Graw Hill Publishing Company.

Mustafid. 2017. Statistika Dalam Proyek Six Sigma. Semarang: UNDIP Press.

Raissi, S. 2009. Multivariate Process Capability Indices On The Presence Of Priority For Quality Characteristics. Journal of Industrial Engineering International, Vol. 5, No. 9, 27-36. 